\title{
PERSISTENT PRIMITIVISMS: POPULAR AND ACADEMIC DISCOURSES ABOUT PACIFIC \& MĀORI CINEMA AND TELEVISION
}

\author{
SARINA PEARSON \\ University of Auckland
}

\begin{abstract}
A triumvirate of films in the twenties and early thirties-Flaherty's Moana (1926), Murnau's Tabu (1931) and to a lesser extent Van Dyke's White Shadows in the South Seas (1928) — consolidated the prevailing and enduring cinematic trope for the Pacific. They established a cinematic archive upon which film and television throughout the 20th century and into the 21 st has drawn (Pearson 2010). All three envisioned the Pacific as a region of isolated, sparsely populated tropical islands whose inhabitants were ideally untainted by commerce or industrialism. They advanced a powerfully persuasive "ethnographic" vision, asserting cultural authenticity predicated in large part on the strength of location shooting. ${ }^{1}$ Their appeal lay in their capacity to provide audiences in Europe and North America not only with exotic imagery, the promise of escape and ethnographic spectacle, but with seductive projections of difference against which they could compare, interrogate and evaluate their own sense of modernity (Geiger 2007).
\end{abstract}

Critics have argued that American audiences watching these films upon their initial release would have recognised that these visions of paradise were highly contrived. Referring to White Shadows in the South Seas, Geiger wrote that "certainly, most audiences in 1928 would have known the unspoiled island at the heart of the film was an invention" (2002: 110). If audiences in the twenties were able to suspend relatively sophisticated knowledge about the scope of colonial intervention in the Pacific in order to indulge in the pleasures of primitivist cinematic spectacle, it is far from clear that contemporary audiences and critics are capable or perhaps willing to do the same. Pacific romanticism continues to exert palpable force in the popular and academic critical literature about motion pictures set in the Pacific. Its persistence is all the more remarkable given the spatial, temporal, socio-political, intellectual and creative milieu that global audiences inhabit and in the types of motion pictures that are currently being produced.

In the last decade a growing cohort of Pacific Islanders based primarily in New Zealand, and henceforth referred to as "Pasifika", ${ }^{2}$ and Māori have been making feature films, dramatic shorts and television series for domestic and international release. Television series such as bro'Town (2004-2009) and 
the film No. 2 (2006) have impressed critics while Sione's Wedding (2006) and Sione's 2: Unfinished Business (2012) have achieved broad popular appeal. Taika Waititi's sophomore feature BOY (2010) accomplished both. ${ }^{3}$ These productions have not only been shaped by conditions of modernity, particularly by the dictates of transnational capital, global audiences and the culture industries, but many of them foreground how Pacific subjectivities are now profoundly enmeshed in complex global repertoires of mediated images and narratives (Appadurai 1996, Hokowhitu 2012, Smith, 2012). The characters in bro' Town, Sione's Wedding and $B O Y$ are no longer ciphers onto which Western fantasies (erotic or otherwise) can be projected, nor are they consigned to authenticate isolated exotic tropical locations. Instead the boys on bro'Town are experts on Little House on the Prairie (1974-1983) trivia, the best mates in Sione's Wedding text away in dank urban singles bars, and the protagonists of BOY mash-up Michael Jackson's Thriller with kapa haka. ${ }^{4}$

Film critics and media scholars, faced with the escalating unfeasibility of maintaining the fictions that underlie historically pervasive primitivist tropes of timeless Pacific tradition and isolated innocence, might reasonably be expected to have engaged with these developments. ${ }^{5}$ Yet, the criticism generated (and sometimes not generated) in academic studies and among film critics reveals that "romantic" ways of thinking about Pacific cinematic and televisual representation are not so easily discharged. Even politically progressive narratives find themselves subject to the gravity of romanticism. The sheer persistence of assumptions in the analytical literature that continue to cast Pacific subjects as timeless, innocent and primitive remind us of the resilience of what Trouillot calls "the Savage slot" (1991, 2003).

\section{THE SAVAGE SLOT}

Trouillot describes "the Savage slot" as a structural repository integral to organising the project of global legitimation referred to as "the West". He quips "ever since the West became the West, Robinson has been looking for Friday" (Trouillot 2003: 17). Historically the West's vision of order relied on the existence of two complementary spaces configured as "the here and the elsewhere". Both were "premised [upon] one another and were conceived as inseparable" (Trouillot 1991: 32). "Elsewhere" was figured as utopia and although theoretically it could be anywhere, in the context of the geo-political conquest incited by Columbus's rediscovery of the Americas, it effectively became a colonial space inhabited by "others". These others (who axiomatically originated from elsewhere) became "the Savage": a North Atlantic projection that enabled the West to consolidate and define its own sense of self. ${ }^{6}$ 
The Savage slot's content was never fixed and therefore capable of attributing widely divergent qualities to its occupants. Savages could "be noble, wise, barbaric, victim or aggressor, depending upon the debate and on the aims of the interlocutors" (Trouillot 2003: 23). They nevertheless captivated the Western imagination for more than 500 years, inspiring a wide range of literary and cinematic practices as well as academic pursuits. ${ }^{7}$

Trouillot delineates the Savage slot in his attempt to propose solutions to the disciplinary crisis anthropologists experienced in the $80 \mathrm{~s}$ and $90 \mathrm{~s}$. He observes that charged with formally studying and producing knowledge about primitive others, anthropology progressively lost sight of its object of study over the course of the 20th century. Subjects of ethnographic inquiry were no longer neatly contained in remote and timeless locales. The tides of modernity progressively eroded the primitive's once unambiguous alterity and anthropologists whose raison d'être involved simultaneously chronicling the Savage's primordialism and his or her humanity now faced a potentially unhappy fate. In the field, the anthropologist

camera and notebooks in hand,...[looks] for the Savage, but the Savage has vanished. The problem starts with the fated inheritance of the moderns themselves. The world that the anthropologist inherits has wiped out the empirical trace of the Savage-object: Coke bottles and cartridges now obscure the familiar tracks.... Lingering conditions of modernity make the notion a hard one to evoke in imagination, now that hordes of Savages have joined the slums of the Third World or touched the shores of the North Atlantic. (Trouillot 2003: 24)

According to Trouillot, the resolution to anthropology's crisis involves acknowledging and embracing the world that modernity has produced rather than persistently repudiating it. "With refugees at the gates, diasporas in the midst, and peasant kids dreaming of Nike shoes, most anthropologists cannot deny that the world has changed and that therefore the discipline that claims to cover the whole of humanity must also change" (Trouillot, 2003: 118). Anthropologists are advised to deconstruct the symbolic order upon which the discipline was founded; to destabilise the Savage slot by legitimising rather than marginalising indigenous discourse. This manoeuvre would produce dynamic and contested fields of knowledge, rather than reinforcing what the West knows about the rest. The ensuing fields of knowledge would be inherently plural and specific. "Once we pluralize the native, the category itself becomes untenable and the Savage slot becomes open to deconstruction" (Trouillot 2003: 136).

The Savage slot is already under this type of pressure from various creative quarters. In the contemporary Pacific, exhibitions such as One Noble Savage 
and Two Dusky Maidens (Hastings-McFall et al. 2000) and works such as Shigeyuki Kihara's Fa'afafine: In the Manner of a Woman (2004-2005) ${ }^{8}$ satirise colonial stereotypes. The multimedia collective Pacific Sisters attest to the collapse of the divide between the West's here and the Savage's elsewhere by producing work inspired by their urban contexts. Pacific Sister Rosanna Raymond has stated, "We get our inspiration from our immediate urban/media environment....We don't stare at coconut trees-we stare at motorways" (Raymond 1997). ${ }^{9}$ These artists distance themselves from romantic assumptions about paradisiacal primitives, asserting the modern quotidian context in which they live and work.

Postcolonial developments in cinema, performance and fine art fortify Trouillot's optimism about anthropology's futures and its capacity to unthink the Savage slot (Trouillot 2003: 137-39). Indigenous scholars in New Zealand and in the Pacific are also making significant contributions (Hokowhitu 2012, Smith 2012). Perhaps these activities mean that the project stands a chance but it is also quite possible that the Savage slot's power and appeal as a structural category has been underestimated. The West may have irrevocably changed but its project continues to exert tremendous force. As a constitutive co-ordinate of that project, the Savage slot is not easily disestablished. Anthropology has not been the only literary practice susceptible to its force; film and media studies are implicated as well.

\section{BRO'TOWN}

In the spring of 2004, the prime time animated television series bro'Town, featuring five adolescent Polynesian boys, premiered on New Zealand television. Proclaiming itself "The Simpsons of the South Pacific" (Nippert 2004), the show satirised race relations in the local cultural-scape of Auckland, New Zealand's largest metropolitan centre. Jointly produced by television producer Elizabeth Mitchell and the Naked Samoans, an improvisational theatrical troupe, bro' Town was considered a critical and commercial success. The show's idioms rapidly entered the performative repertoire of the show's most avid and devoted demographic, five to twelve year olds who parroted its vernacular slogans "Morningside for Life", "not even ow" and the sexually suggestive "peow peow" so much so that some local schools finally banned them (Barry 2005).

As "easily the most successful TV show made by and centred to some degree on Polynesians", Bannister reckoned the show was "symptomatic of the cultural ascendancy of Pacific Island diaspora culture" (2008: 1). Although its New Zealand fan base and ratings diminished over the series' five season run (Barry 2009), ${ }^{10}$ the show's overall success at attracting a mainstream audience nevertheless paved the way for subsequent projects made by Pasifika 
key creatives about diasporic Polynesian subjects, including the feature film Sione's Wedding and its sequel Sione's Wedding 2: Unfinished Business.

Perhaps ultimately more South Park (1997-present) than The Simpsons (1989-present), particularly in its use of scatological and puerile adolescent masculine humour, bro'Town derived much of its comedy by exaggerating ethnic stereotypes. The antics of adolescent brothers Vale and Vale'a, their neighbour Sione, and mates Mack and Jeff da Māori in the semi-fictional, inner-city adjacent suburb of Morningside provided numerous opportunities to lampoon stereotypes that characterise Pasifika and Māori as underprivileged, poorly educated, State dependent and prone to domestic violence. The show combined rampant intertextuality with politically incorrect satire, producing critical social commentary. By gleefully attacking both ends of the political spectrum (assumed as middle-class Pākehā ${ }^{11}$ liberals and Polynesian conservatives), the show appealed to a broad audience on the basis of its apparent anti-authoritarianism and irreverence. Subverting stereotype, however, was only one aspect of the show's attack on the Savage slot.

bro'Town rejected cinematic paradisiacal tropes such as those perpetuated by 20 th century South Seas films by situating itself in multi-ethnic suburban settings populated by cosmopolitan characters, narratives and semiotics. The series refused to indulge its audiences' appetite for televisual paradise by ridiculing perceived audience expectations for tropical tropes and primitive sightings in its mise-en-scène. ${ }^{12}$ Furthermore, by repudiating realism with its two dimensional animation the series offered audiences an "informational minimalism" that forced them to interpret the show using their own extratextual knowledge, which they did "by drawing on the vast visual chaos of signs, forms and types that postmodern media and living continually press upon us" (Bannister 2008: 10). bro'Town richly rewarded audiences for their popular media literacy. Its effects, however, arguably exceeded the smug satisfaction that comes from getting inside jokes about syndicated American television. The series potentially offered Pasifika new categories of global inclusion by rewarding rather than disparaging their popular cultural competencies, effectively asserting their place as Western subjects rather than Savage objects. bro'Town's extensive use of intertextuality might place it squarely in the purview of Jameson's (1991) critique of postmodernism where productive parody is effectively dead, having been replaced by clever but superficial and ultimately meaningless pastiche. This approach, however, misses bro'Town's socially and politically affective force. Intertextuality in this instance could been seen as enabling the show to "talk back to more authoritative texts and genres,... recontextualiz[ing] and pollut[ing] their meaning-construction processes, and to offer other, 'improper,' and yet more media literate and savvy interpretations" (Gray 2006: 4). The moral 
pedagogy of the show, although admittedly uneven, nevertheless used prevalent discourses about ethnicity, gender and class to problematise those discourses and expose them as familiar and perhaps pleasurable, but not necessarily "true" (Bannister 2008: 9).

bro' Town was not universally celebrated. A number of prominent Māori and Samoan intellectuals deplored its exaggerated use of stereotype, condemning the series for perpetuating rather than undermining conditions that entrench racial inequity (Anae in Misa 2006, Spratt 2006). For example,

Melanie Anae has argued that bro'Town promotes the stereotype of 'the happy-go-lucky' funny brown coconut that Pacific Islanders 'fought against in the 70s', and that Kightley is one of a number of Pacific artists, playwrights, and entertainers who 'pick the negatives of our cultures and get rich on it by entertaining people'. (Keown 2008: 53)

Wholly legitimate concerns about the show's political effects ironically reinforce the Savage slot. Anae's critique is premised on a conception of identity as essential rather than discursively produced. She criticises bro'Town's failure or its unwillingness to correctly represent "real" adolescent Samoan boys and their community. The conception of a "real" essential (and therefore necessarily singular) Samoan identity, rather than a plurality of Samoan subjectivities and experiences, reproduces conditions under which Samoans are produced as primordial "savage objects" rather than legitimate modern subjects inherent in and in dialogue with the project of "the West".

Comparisons between bro'Town and The Simpsons or South Park are not merely incidental or the effect of "clever marketing" but rather reflect strategies to produce television that straddles both local and transnational values. These values are vital to commercial viability. Lustyik and Smith (2009) characterise bro' Town as a "hybrid media text" that exhibits culturally specific attributes while reflecting "the global synchronization of world markets" (Kraidy in Lustyik and Smith 2009: 335). For television producers, consumers and critics in commercially marginal markets such as New Zealand, hybridity can mean the proverbial glass is half empty or half full. The glass half empty perspective regards bro' Town as a fatal compromise capitulating to the dictates of a transnational television industry and a populist local audience both of which favour a progressively narrowing spectrum of formats that can be hybridised ad infinitum to suit the demands of commercial interests (Lustyik 2010). This approach tends to regard shows like bro' Town as hopelessly derivative and creatively beholden to a set of politically regressive constraints far beyond the producers' or the audience's control. The glass half full approach argues that producer Elizabeth Mitchell and the Naked Samoans acknowledged and engaged with the conditions under which they could 
maximise their chances for commercial and creative success rather than be alienated by them. They faced risk because New Zealand television producers have struggled with comedy. Animation is notoriously expensive, labour intensive and, in the New Zealand context, relatively uncharted territory. However, the gamble Mitchell and the Naked Samoans took, if successful, capitalised upon animation's broad appeal. Animation reputedly transcends national cultural boundaries more easily thereby increasing its commercial viability. ${ }^{13}$ It also has a longer shelf life and often enjoys a lucrative symbiotic relationship with merchandising. Both approaches, half empty and half full are potentially valid, but the choice to produce animated comedy could be seen in many respects as a bold manoeuvre that reflected hybridising trends in other indigenous Pacific-based productions such as the Māori science fiction series Mataku (2002-05).

\section{TRANSNATIONAL TELEVISUAL HYBRIDITY}

Television producers, journalists and academics have described Mataku (The Quivering) as a kind of Māori X-Files (Glynn and Tyson 2007) or an incarnation of the Māori Twilight Zone (Cardno and Prebble 2002: 74). The series aired on commercial New Zealand broadcaster TV $3^{14}$ and the public service oriented Māori Television Service (MTS) in primetime between 2002 and 2005. It combined characteristics from supernatural, magical realist television genres such as the X-Files (1993-2002) or Tales from the Crypt (1989-1996) with "treasured stories that often concern cosmic supernatural payback dealt to those who've broken tapu or transgressed against the spirit of the land" (Glynn and Tyson 2007: 214). Mataku has generally been celebrated as an example of hybrid television that facilitates the production of an indigenous public sphere because of its use of te reo Māori,${ }^{15}$ its subject matter and its use of magical realism. Series co-creators, Bradford Haami and Carey Carter, began developing Mataku in the early 90s but progress on the project had effectively stalled until financial backers recognised the series' international potential. ${ }^{16}$ Glynn and Tyson (2007) describe the cruel circularity that has doomed most indigenous projects because mainstream media and audiences are deterred by their anti-colonial critique. "Indigenous mediamakers' historical focus on the production of interventionist programming... reinforces television networks' perception that indigenous content alienates majority audiences" (Glynn and Tyson 2007: 208). By engaging with the parameters and values set in the transnational televisual marketplace, the makers of Mataku achieved twin objectives: to produce "indigenous narratives through the frameworks of globally familiar generic models, while... continually reassert(ing) and reestablish(ing) the distinctiveness of Māori connections to Aotearoa, to the land" (Glynn and 
Tyson 2007: 216). The series' successful international sales record prompted observers to describe it as the most successful Māori television series to date. Mataku's success arguably paved the way for subsequent supernaturally inflected series such as the Kaitangata Twitch (2010), which also combined magical realism and drama. A more recent example of generic hybridity, however, was the reality television series The G.C. (2012), which represented Māori transmigration to Australia's Gold Coast using a premise and style that mimicked two of MTVs scripted reality series: The Jersey Shore (2009-2012) and The Hills (2006-2010),

Albeit narratively dissimilar, both Mataku and bro'Town instrumentally aligned themselves with transnationally established genres to demonstrate their viability to network gatekeepers. Audiences unfamiliar with these series' cultural contexts or marginally unsympathetic to their politics may nevertheless have watched the shows on the basis of their genre. In this respect transnationally ascendant genres "need not be an agent of Western cultural imperialism but rather can be used to assert local interests and priorities" (Parks in Glynn and Tyson 2007: 212). bro'Town and Mataku harnessed genre to expand their influence and registers of sentiment.

Despite strategically engaging with transnational commercial television to fulfil very similar objectives, these series engendered significantly different critical responses. Critics praised Mataku as a strategic intervention in the indigenous and Māori public sphere whereas bro'Town's role in raising the profile of Pasifika and legitimating diasporic Pacific cultures was greeted with some suspicion. In part this may have been attributed to the fact that Mataku's heavy emphasis upon spirituality largely conformed to domestic and international expectations of Māori subject matter. ${ }^{17}$ Kaitangata Twitch similarly invokes Māori magical realism. As will become evident when discussing $B O Y$, these expectations constitute yet more evidence of the forces exerted by the Savage slot. Critical and popular perceptions of Mataku's funding, through national public service agencies such as Te Mangai Paho, ${ }^{18}$ New Zealand on Air and the New Zealand Film Commission also conspired to produce a sense of ethical purity that similarly imbued the series with an aura of noble savagery. bro' Town, by contrast, was partially financed through commercial sponsorship. Its explicit engagement with advertising and marketing subsequently became sites of discursive tension for the series.

PRODUCT PLACEMENT AND ACCUSATIONS OF CORPORATE CORRUPTION

Still, bro'Town was largely financed by New Zealand on Air (NZOA), the quasi-governmental agency charged with funding local New Zealand television content. As one might expect with government funding, NZOA funds are also earmarked to support the local television production industry. 
bro'Town's intensive 2D animation meant that each episode required a workforce of about 150 animators (Toonboom 2006). Faced with a small and inadequate local labour force, Mitchell set up a small studio in Auckland and outsourced significant amounts of the workflow, first to India and then subsequently to the Philippines (Mitchell 2009). The conditions under which NZOA funds were granted for bro' Town did not permit production expenditure overseas, therefore Mitchell was compelled to raise private finance. Granted NZ\$1.45 million from NZOA for the first series, Mitchell had to fund the balance of the first season's two million-dollar budget through alternate means (Wakefield 2004). She raised the shortfall through product placement capitalising upon advertiser interest in Polynesian youth.

One of the most sustained analyses of bro'Town has been a critique of its relationship to commodification (Earl 2005, 2006). Earl argues that despite its irreverent and subversive posture, bro' Town failed to "pry open new discursive spaces for the development of youth identities" because its counter-hegemonic stance was fatally compromised by the show's reliance on corporate sponsorship" (Earl 2006: 58).

In a country where advertising executives once openly defended the fact that "there are more dogs shown on commercials than there are Māoris [sic] and Polynesians" (Harvey in Scott 1990: 84), and television executives routinely asserted that ethnic minorities fail to rate, the change in New Zealand's media-scape has been dramatic. Greater Pasifika visibility in marketing has been attributed to advertisers' increasing sensitivity to the ascendance of multiculturalism as a commodity discourse, particularly among young people (Earl 2005: 3). Actual on-the-ground ethnic diversification attributable to increasing immigration partially accounts for greater media diversity but ethnic difference is disproportionately signified as young and Polynesian. New immigrants, most of whom are East and South Asian, remain largely invisible in advertising and on prime time television, thereby supporting the contention that Pacific youth have been singled out as "it kids" by advertisers (Earl 2005).

Greater visibility, however, does not necessarily translate into greater Polynesian youth empowerment. Earl argues that Polynesian youth have been symbolically appropriated for a kind of soft or boutique multiculturalism that serves to localise and indigenise global products (Earl 2005: 8). Therefore, Pasifika functions to signify a pluralist and inclusive politic without fundamentally challenging "the social authority of male ethnocentrism in Aotearoa New Zealand" (Earl 2005: 3). This line of argumentation is premised upon the assertion that capitalism and its handmaiden commodification can be characterised as exclusively Euro New Zealand values (Earl 2006: 56). Earl cites a history of structural inequities that have disproportionately privileged 
middle-class male New Zealanders of European descent as the basis for ethnically inflected notions of capitalism (Earl 2006: 56). Her argument is problematic, not only because it reduces the potentially complex ideological effects of commercial television to its economics (Bannister 2008: 3) but also because by characterising capitalism as a strictly Western institution, bro'Town's makers and audiences are firmly relegated to the Savage slot, doomed to commercial victimisation and ideological deception, forever acting as unwitting agents in their own oppression. This framework denies bro'Town's fans complex subjectivities and stakes in global modernity despite the series' assertions otherwise. Instead Pasifika are considered fatally distracted by expressing their identity through regimes of consumption.

Considerations of commerce and its effects on ideological discourse significantly temper utopian readings of popular culture's subversive potential. There is a difference, however, between tempering the hyperbolic claims of bro'Town's producers and reconstructing Pasifika as latter day primitives. The danger in Earl's argument is not that bro'Town potentially perpetuates unequal relations despite its subversive rhetoric, but that it perceives commodification as strictly exploitative and Western. This approach, although sensitive to inequality, divests Pasifika not only of participation in modernity, which is significantly shaped by capital, but of the possibilities of prevailing in that context, thereby making inroads into Pākehā privilege.

Product placement is considered pernicious because of its tendency to blur the sacrosanct divide between advertising and editorial content. There is a deep-seated suspicion that, under the terms of product placement deals, marketers will ultimately wield undue creative control. Approximately 10 percent of bro' Town's budget was ultimately derived from product placement (Mitchell in McKenzie-Minifie 2006). Sponsors included transnational corporations such as telecommunications provider Vodafone, apparel company Puma, Coca Cola and Mars, Australian financial institution ASB, New Zealand beverage manufacturer Frucor, and marketing firms such as Positively Wellington, as well as public service institutions such as SPARC (Sport and Recreation New Zealand). ${ }^{19}$ Although Earl's analysis focuses on a number of corporations, she placed particular emphasis upon Vodafone and Coca Cola $(2005,2006)$, fortuitously foregrounding the prominent symbolic role that Coke plays both in Trouillot's work and as a key signifier of modernity at large (Foster 2008).

Every act of telecommunication in bro' Town was made on a clearly marked Vodafone phone and premium internet access services such as "Vodafone Live" were prominent. Earl argues that the show allowed "Vodafone to present cell-phones as an essential aspect of the contemporary youthscape in Aotearoa New Zealand irregardless [sic] of the cost of the product" (2006: 66). The 
expensive models "placed" in bro' Town were an issue because this type of marketing encourages a predominantly Pasifika audience, which is twice as likely to be classified as low income, to aspire to and/or purchase goods they could ill afford. bro'Town's hip Polynesian masculinity therefore hailed audiences who heretofore had not seen themselves as part of the local mediascape, but only insofar as they were able identify themselves by purchasing superfluous commodities.

The accusation that Vodafone preyed upon impressionable young minds (and wallets) was undoubtedly valid in a number of respects, but the symbolic capital of cell phones as an expression of and medium through which to perform modern Pacific youth subjectivity might have exceeded the branding strategies of a telecommunications service provider on bro'Town. While Vodafone could be seen to be capitalising upon the caché that cell-phones have among youth audiences, there are other complicating visual representations that demonstrate how cell phones represent modern subjectivities and mediate contemporary social relations.

The pan-Polynesian rhythm and blues group Nesian Mystik was a recurrent signifier for critical discourses about bro' Town, both directly as the composers for the show and indirectly through rhetorics of multiculturalism and commodification. The band did not just score bro' Town, but one of their Top Ten hits served as the basis for a Coca Cola television advertising campaign in 2004. The television spot featured an attractive group of multicultural youth at a beach party where individuals snowboarded down an ice ramp into an inviting ocean. Earl critiques this campaign as yet another example of the ascendance of multicultural discourse in consumption-based citizenship (2005). She argues that Coca Cola co-opted Nesian Mystik's single "For the People" because it coincided with the corporation's branding strategy to represent attractive, cool, multicultural groups engaged in commodified rebellion rather than genuine political engagement (Earl 2005). Her critique, however, is potentially complicated by earlier mediations of the song.

Before Coca Cola's co-optation of the single, Nesian Mystik made a music video for "For the People". ${ }^{20}$ This video featured each of the members of Nesian Mystik as they went about their daily routine on a Friday afternoon before an evening party at one of their families' Grey Lynn homes. ${ }^{21}$ Beginning at the home of Nesian Mystik Feleti Strickson-Pua the transitional element between each band member was a texted photo. The video placed a significant emphasis on the social and ethnic geography of Grey Lynn, emphasising the role of family and food in social life. The "party" to which the song's chorus referred was not Coca Cola's cool, contained beachside multicultural rebellion but rather the close knit, inter-generational, pan-Polynesian networks in Auckland's inner city suburbs. Cell phones in this context were not intrusive 
agents of Western neocolonial capitalist hegemony but instead could be seen as technologies facilitating "traditional" values of affect, sociability, kinship and creative collaboration.

Earl's argument assumes that Pasifika cannot be included in discourses of consumption because these inevitably involve their unethical production as a market for unaffordable commodities and as symbols of "feel good" pluralist consumption for the hegemonic mainstream. These assumptions reveal key expectations and values associated with this particular incarnation of the Savage slot. Pasifika become latter day victims of consumption rather than participants in modernity. The taint of commodification is not limited to soft drinks and mobile phones. Taken to its logical conclusion, Earl's argument reveals an assumption that in order to be considered politically legitimate, Pasifika media practices should be publicly funded rather than privately. In the case of Mataku, where the series was funded publicly and its political pedigree explicitly anti-colonial, the series has been celebrated for its bold hybridity, whereas bro'Town's politics have attracted suspicion because of its corporate connections.

\section{CRITICAL SILENCE: SIONE'S WEDDING}

In the midst of bro'Town's initial success, two New Zealand based Pacific films were released in 2006: Sione's Wedding (released in the United States as Samoan Wedding) and No. 2. Both films engendered debates about authenticity. Sione's Wedding was co-written and directed by non-Samoans ${ }^{22}$ and although No. 2 tells the story of a Fijian matriarch and her children, no ethnic Fijians were cast. Both films were well covered in the local popular press. No. 2 received more favourable critical attention in part because the film was based on Toa Fraser's award winning play of the same name. Sione's Wedding was considered commercially successful, ranking the fifth most profitable New Zealand film as of December 2012 (New Zealand Film Commission, 2013). ${ }^{23}$ In different respects then, both films were landmark events (Tamaira 2007). In casual conversation filmmakers, audiences and critics alike had plenty to say about these films including a significant amount of criticism. It is curious then that neither produced much if any critical discourse. ${ }^{24}$

It is possible that the lack of critical dialogue about Sione's Wedding was attributable in part to a sense of decorum. If one had nothing nice to say, one should say nothing at all, particularly when films like this one marked a significant intervention in the otherwise relative invisibility of Pasifika in the national media-scape. The lack of critical engagement with Sione's Wedding however, may also have been attributable to its bro'Town-like relation to commodification. The film's protagonists drink Stella Artois, talk on Vodafone 
Sony Ericssons and eat McDonald's takeaways but its populist pedigree was more likely to blame. The lack of predictable angst-laden, tension filled narratives of migrant displacement, loss and pathology in conjunction with the film's romantic comedy pedigree undoubtedly contributed to the silence surrounding Sione's Wedding. In one of the only academic reviews about the film, special mention is made of the film's "ebullience" and its un-conflicted portrayal of a group of New Zealand Samoan men.

The young protagonists of Samoan Wedding are not riddled with the anxiety of trying to negotiate their way between tradition and modernity; instead their feet are firmly planted in both worlds.... These cultural chameleons are as comfortable attending church on a Sunday morning (barring a hangover from the evening before) as they are sipping cappuccino in a swanky inner city café. (Tamaira 2007: 655)

The film is about four 30 -something lads who must demonstrate their maturity by proving that they can sustain romantic relationships. The premise is slightly frivolous and the resolution of their dilemma is similarly light. The film's protagonists are immature and self-conscious rather than disenfranchised and angry. They are middle-class and urban rather than impoverished and dispossessed. They may hold traditional values but they are not romantic primitives and they fail to perform according to well-established tropes. As a result, the film may not have been visible to critics anticipating "something else". It looked too much like entertainment, thereby collapsing the critical divide upon which the Savage slot is premised. The film's politics are not explicitly stated but rather implied in its emphasis upon middlebrow heteronormative romance and its urban first world mise-en-scène. In this instance the Savage wasn't sufficiently sighted for Sione's Wedding to be cited in critical discourses about popular culture and performance in the Pacific.

\section{EXCESSIVE MODERNITY: $B O Y$}

If critics overlooked Sione's Wedding the same cannot be said for Taika Waititi's BOY. Following its premiere at the 2010 Sundance Film Festival, Variety reviewer Peter Debruge described the film as a "let-down second feature expanded from his Oscar nominated short, "Two Cars, One Night" (2010). Debruge's critique derived largely from $B O Y$ 's frequent references to American popular culture. Based on Waititi's childhood experiences in the rural settlement of Waihau Bay on the East Cape of New Zealand's North Island, $B O Y$ was a coming of age story about 12 -year-old Boy and his younger brother Rocky's encounter with their ne'er-do-well father Alamein. In many respects the story was all too familiar for a Māori film. It featured child neglect, disenfranchisement, criminality and domestic dysfunction but 
Waititi asserted that his film broke new ground by giving these depressingly well-established narrative themes a comedic twist. ${ }^{25}$ Debruge nevertheless remained unimpressed, objecting to the many markers of modernity and globalisation present in the film. He lamented, "long since severed from their tribal past, these kids have names derived from pop culture-like Dynasty, Dallas and Falcon Crest" (Debruge 2010). Extended references to Michael Jackson, in the narrative itself but presumably also in the Poi E-Thriller mash-up that accompanied the credits simply fuelled Debruge's displeasure. He betrayed his desires to sight the Savage by decrying the film's lack of "spirituality", writing "only Boy's kid brother Rocky (Te Aho EketoneWhitu), seems remotely spiritual" (Debruge 2010). Debruge concluded that without what he describes as "anthropological edge" the film would fail to attract independent film's all important international art house audience.

Debruge's comments met with swift and heated local response. Actor Tammy Davis, responded by rebuking Debruge's exoticist expectations. He posted the following comment on Variety's website,

Peter, growing up Māori on the East Coast of New Zealand is not all riding whales. What culturally specific aspects were you missing? Were young Māori in the early 80 s too busy learning to keen and chant and wail to be concerned with schoolyard crushes and the phenomenon that was Michael Jackson? Then I am afraid to say I am a let down of a Māori, because in the 80 s this was all there was for me. (Davis, in Wichtel 2010)

Waititi responded with similar irritation to the reviewer's primitivist expectations, observing that cinematic desires for spiritualism and ethnographic authenticity are fulfilled and fuelled in ways that make those desires prescriptive. His response was predicated in part upon the positive international reaction to The Whale Rider (2002), a film also set on the East Cape but one that characterises contemporary Māori as spiritually tied to nature and largely isolated from the outside world. Waititi gently mocked Debruge's exoticist expectations on BOY's official website by including a small figure riding a breaching whale on its splash page. ${ }^{26}$

Debruge's review also provoked a reaction among indigenous academics. In 2012 Jo Smith and Ocean Mercier edited a special edition of the New Zealand Journal of Media Studies dedicated to BOY. Although diverse in their opinions about the emancipatory potential of the film (some contributors felt Waititi successfully subverted the Savage slot [Huarcaya 2012], while others felt that the film reproduced colonial disenfranchisement [Kavka and Turner 2012, Pihama 2012]), the contributors to the volume nevertheless consistently took Debruge to task for his retrograde anthropological desires (Hokowhitu 
2012, Smith 2012). Smith, in particular criticised him for failing to accord indigenous filmmakers the same rights as other directors to openly imagine and create narratives of identity (Smith 2012: 4).

It is tempting to dismiss an American film reviewer like Debruge as hopelessly misinformed about the metropolitan aspects of the contemporary Pacific. It is also quite possible to dismiss the kind of criticism published in a trade journal like Variety as intellectually inconsequential. Debruge's assumptions, however, as unpalatable as they might seem, are nevertheless significant. Trade reviews influence box office performance. Box office returns reflect a film's distribution and determine to some extent the likelihood of a director's subsequent creative opportunities. Ticket sales are not a definitive measure of success or value, but they are worth considering. Debruge's lukewarm review resonated with international box office figures. Whereas $B O Y$ earned NZ \$9.3 million in New Zealand, it earned an underwhelming US \$256,000 dollars in the U.S. (Box Office Mojo 2013a). This sum was significantly more than Sione's Wedding, which earned US \$72,244 under the title of Samoan Wedding (Box Office Mojo 2013b), but significantly less than Whale Rider, which earned over US \$20 million domestically and internationally (Box Office Mojo 2013c). These figures support Debruge's prediction that films such as Whale Rider, which promote romantic visions of Māori indigenous spirituality and closeness to nature appeal to international audiences looking for what they perceive as an anthropological allegory. To some extent $B O Y$ 's failure to turn its critical success at Sundance and The Berlin International Film Festival into international box office receipts suggests that distribution companies shared Debruge's 'highly prescriptive views on what an Indigenous filmmaker must provide' (Smith 2012: 66). Distribution companies are significant here because of the gatekeeping role they play. Audiences only see and develop tastes for what becomes available to them. Despite $B O Y$ 's domestic box office success and international recognition, no international distributor was willing to take it to the American market (Silverman 2012). In the end, a consortium of small independent U.S. distributors (Unison, Radius and Paladin) distributed the film independently with Waititi raising the print and advertising budget through the crowd funding website Kickstarter (Daniell 2012). Ultimately, $B O Y$ was released in a very limited number of cities ranging from New York and Los Angeles to Salt Lake City and Santa Cruz. In stark contrast Whale Rider was picked up by Newmarket Films, a well-financed distributor who entered the North American market aggressively, capitalising upon the favourable response of festival audiences to the film's mysticism (Berney in Toumarkine 2003: 20), its armchair anthropological approach (Hokowhitu 2007), and its economic value as a rare film that adults could take their kids to (Laemmle in Ross 2012: 30). 
The international expectations about anthropological allegory and good indigenous filmmaking that underpin Debruge's review cannot be dismissed as merely idiosyncratic or personal. Indeed the Variety reviewer for the Samoan film The Orator (2011) also invokes anthropology in her review. In this instance she reports that director Tamasese "explodes myth" and "balances cultural insight with storytelling" that renders the "exotic comprehensible" producing a film that has more than "merely anthropological interest" (Felperin 2011). Notwithstanding the fact that her review is positive and Debruge's borders on negative, the anthropologically authentic South Seas cinematic standard against which they implicitly judge contemporary Pacific and Māori film is discernible.

$$
* * *
$$

Critical and popular discourses that detect traces of "Cokes and cartridges" or, in the case of $B O Y$, Michael Jackson and the comic character the Incredible Hulk, have produced criticisms that reveal the ongoing presence of a political economic, thematic and narrative Savage slot operating in Pacific representation. Rather than enacting vernacular modernities in circumstances not entirely under their own control, Pasifika seem to be imagined as properly outside of global popular culture and regimes of commodification. If they do participate in commodity relations they are immediately dupes of Euro-New Zealand hegemonies, doomed to participate in their own dispossession.

bro'Town's claims to subversion and irreverence need to be considered in the context of televisual promotion rather than as hard evidence of a politically formulated agenda. The producers of the series bro'Town might have aspired to effect social change (and arguably they did in the schoolyard and perhaps even beyond) but they were also impelled to promote the distinctiveness of their product, which they did by emphasising how the show intervened in New Zealand's heretofore televisual whiteness. While the series may have failed to pry open emancipatory spaces in which complex Polynesian youth identities could be articulated (Earl 2006: 61), the series clearly opened spaces for more Pacific visibility in the public sphere. It also produced capital and ongoing professional opportunities for the Naked Samoans, even if it did so in addition to lining the pockets of TV3's owners Ironbridge Capital. Criticising the series for exploiting Vodafone's marketing strategies reduces the social dynamics of cell phone use to affordability, when clearly cell phones are used to signify more than simply "to have is to be". Cell phones appear to constitute part of a repertoire for performing Pasifika modernities and can be seen as a small intervention in discourses of persistent primitivisms. 
In the case of Sione's Wedding performing modernity in the form of a well-established genre rendered the film all but invisible to cultural criticism. Audiences may have flocked to the film, but academics failed to detect the usual harbingers of migrant distress and indigenous angst, and therefore looked towards more predictably controversial and contentious quarters. Performing modernity, however, does not always produce the same results. In $B O Y$, critics registered the hallmarks of modernity, symbolised almost entirely by electronic media, with disdain and disappointment, thwarted in their desire to "sight the Savage".

Contemporary Pacific romanticism may carry the trace of its 20th century antecedents but it has also proven highly adaptive, incorporating new elements such as public service broadcasting, non-genre narratives and realist aesthetics into its Savage slot. Its enduring omnipotence is signalled by its capacity to underpin both progressive liberal discourses, as is the case in Earl's argument where her objective is to critically interrogate falsely inclusive multicultural discourses, and Debruge's unapologetic desire for primitive holism and heightened spirituality. In her polemic to shake the anthropological frame Smith asks, "Why can DeBruge [sic] not see Waititi's refusal to deliver more domesticated ideas of Indigenous culture as an expression of the endlessly transformative dimensions of Indigenous articulations?" (Smith 2012: 67). The answer may lie in the structurally sticky, persistent nature of the Savage slot and the multiple registers (popular, academic, political) throughout which it operates. Current critical discursive practice suggests that these romanticist assumptions are more difficult to un-think and undo than social scientists and humanities scholars in the Pacific might have anticipated.

\section{NOTES}

1. The opening title sequence to Moana: A Romance of a Golden Age establishes that the Flahertys lived in a village on Savai'i for two years and consulted with a culturally knowledgeable and well-connected translator (Fialelei, the granddaughter of Seumanutaga). Tabu opens with a title card that assures audiences that the film features "only native-born south sea islanders... with a few half-castes and Chinese". White Shadows in the South Seas makes similar claims to authenticity except that they were inaccurate. MGM claimed the film was shot in the Marquesas with authentic Marquesans but it was shot in Tahiti (Geiger 2007: 263). Regardless of the relative veracity of these opening claims, their narrative role nevertheless functioned to ensure that audiences read these films as displaying real people and places, rather than openly imagined ones.

2. Pasifika is used to officially denote New Zealand based Pacific peoples by organisations such as the Ministry of Education. In an article for the New Zealand Herald, Perrot describes the term as the "... samoanisation of a Portuguese nod 
to the Latin phrase Mare Pacificum, or peaceful sea, so named by navigator Ferdinand Magellan.... it has become an umbrella term for everyone living here with traceable Pacific Island heritage. You'll find it touted enthusiastically by governmental social ministries and schools" (Perrot 2007).

3. $B O Y$ is included as part of this emerging corpus of work because critics outside New Zealand include Māori filmmaking as part of the Pacific oeuvre (Douglas 1994, Mawyer 1998) and because BOY deploys tactics (such as its use of ironic humour) that coincide with significant trends in Pasifika motion picture, attesting to the representational affinities between indigenous Māori and Pacific migrants (Somerville 2005, Teaiwa and Mallon 2005).

4. Kapa haka refers to a performance of traditional or contemporary Māori song and dance.

5. Indigenous film scholars who have critiqued vexed relations with modernity and global popular culture in a special edition of the New Zealand Journal of Media Studies dedicated to the film BOY are an exception (Smith and Mercier 2012).

6. Trouillot carefully pointed out that regarding the savage or primitive as the West's alter ego is simplistic; that in fact the alter ego is Janus faced: “... of whom the savage was only the second face. The first face was the West itself, but the West fancifully constructed as a utopian projection and meant to be, in that imaginary correspondence, the condition of existence of the savage" (Trouillot 1991: 28).

7. Trouillot focused upon literary practices but he makes fleeting reference to the role that other media play in constructing the Savage slot. He wrote, "Anthropology came to fill the savage slot of a larger thematic field, performing a role played, in different ways, by literature and travel accounts - and soon to be played perhaps by unexpected media, if one takes the success of 'Roots,' 'Miami Vice' or 'China Beach' on North American television... as a future” (Trouillot 1991: 29).

8. For Kihara's photographs as a dusky maiden with a difference, see http://www. shermangalleries.com.au/artists/inartists/artist.asp\%3Fartist=58\&exhibition=90. html.

9. Raymond's 2006 project Pasifika Styles (curated with Amiria Salmond) at the Museum of Archaeology and Anthropology in Cambridge represented another incarnation in which Pacific artists interrogate the historical past and modernity.

10. The first series of bro' Town (2004) 'attracted 33 percent of the viewing audience during its 8 pm time slot, 24 per cent in 2006 and 20.3 percent in 2007” (Barry 2009).

11. Pākehā refers to the descendants of British New Zealand settlers but it can also be used more generically to refer to European New Zealanders.

12. See bro'Town episodes Survival of the Fattest (Season 2) and An Alien at my Table (Season 4).

13. Havens (2006) noted the commercial appeal of animation and the merchandising synergies between animation and the marketing of toys, fast food and DVDs. Lustyik presented a case study of Nickelodeon's operations in New Zealand as an example of how the network exploits its significant animation catalogue in multiple territories (Lustyik 2010: 175).

14. bro'Town aired on TV3 as well. 
15. Te reo means Māori language.

16. South Pacific Pictures CEO John Barnett was one of the financiers who recognised Mataku's international potential (Glynn and Tyson 2007: 215).

17. Hardy noted (2012: 11) that several recent Māori films such as The Strength of Water (2009) and Matariki (2010) as well as BOY exhibit the presence of "a loose template for an effective 'spiritual' film, one that links the pantheistic beliefs of traditional Māori lifeworlds with the expressive spirituality in popular in the contemporary secular cultures". Although Hardy characterised spirituality in New Zealand film as an antipodean phenomenon, she acknowledged the tendency for Māori expression of spirituality to find critical acceptance while contemporary Pākehā films with similar types of content, such as The Vintner's Luck (2009) find less. The reasons are complex but the discrepancy suggests that audiences expect and accept spirituality more readily when expressed as indigenous.

18. Te Mangai Paho is a government agency charged with funding Māori Language broadcast media. The New Zealand Film Commission supports national short and feature film production.

19. The presence of public service institutions such as SPARC complicate Earl's argument inasmuch as these organisations promote values such as physical fitness and healthy living that are in the public interest. These are values that are presumably consistent with what Earl sees as bro'Town's self-advertised progressive political agenda with respect to Pasifika youth identities.

20. New Zealand on Air contributed $\$ 5000$ toward the music video for For the People in June 2002 on the basis of the single's radio play potential (NZOA 2011).

21. Grey Lynn is an inner city Auckland suburb where many Pacific Island migrants settled in the 1970s. Despite the significant gentrification that this neighbourhood has undergone and the movement of many Pasifika families to the southern and western suburbs of the city, Grey Lynn nevertheless continues to play a significant role in the geographic imaginary of Pasifika and various institutions such as churches are still located there.

22. Prolific television writer James Griffin was co-writer and veteran music video director Chris Graham directed. See Henderson (2004) for background on Chris Graham's links to hip hop and music video direction.

23. No. 2 made $\$ 753,355$ as of 27 July 2010 according to the New Zealand Film Commission (2010).

24. A survey of film reviews and academic articles about recent films about Pacific peoples indicates that The Orator (2011) has generated a far more significant response than the Sione franchise or No. 2. A significant reason for this attention is that The Orator was filmed on location in the Samoan language. For example, The Contemporary Pacific published four reviews of The Orator in their fall edition of 2012 (Henderson 2012, Kihleng and Teaiwa 2012, Muiava and SuaaliiSauni 2012, McFarland-Tautau and Hunkin 2012). Metro published an interview and references have been made to the film in two articles published in Studies in Australasian Cinema (Hardy 2012, Huffer 2012).

25. Leonie Pihama (2012) expresses disappointment at what she sees as a continuation of Māori dysfunction and distress in Māori cinema. Kavka and Turner (2012) 
also note how some of the ways in which $B O Y$ fails to subvert or problematise the settler politics that overdetermine Māori film.

26. See $B O Y$ 's official website: http://www.boythemovie.co.nz/

\section{REFERENCES}

Appadurai, A., 1996. Modernity at Large: Cultural Dimensions of Globalization. Minneapolis: University of Minnesota Press.

Bannister, M., 2008. Where's Morningside? Locating bro'Town in the ethnic genealogy of New Zealand/Aotearoa. New Zealand Journal of Media Studies 11 (1): 1-15.

Barry, R., 2005. bro'Town returns as its animation empire expands. The New Zealand Herald, 27 August. Available at: http:/www.nzherald.co.nz/tongansinnz/news/ article.cfm?c_id=346\&objectid=10342595 (accessed 23 December 2010).

-2009. Farewell to Morningside. The New Zealand Herald, 18 April. Available at: http://www.nzherald.co.nz/youth/news/article.cfm?c $\mathrm{id}=107$ \&objectid=10567701 (accessed 10 January 2011).

Box Office Mojo. 2013a. Boy. Available at: http://www.boxofficemojo.com/movies/ ?page=weekend\&id=boy2012.htm (accessed 21 January 2013).

-2013b. Samoan Wedding. Available at: http://boxofficemojo.com/movies/ ?id=samoanwedding.htm (accessed 21 January 2013).

_-2013c. Whale Rider. Available at: http://boxofficemojo.com/movies/ ?id=whalerider.htm (accessed 21 January 2013).

Cardno, J. and A. Prebble, 2002. The M Files. The New Zealand Listener, 28 September, 74.

Daniell, S., 2012. Twelve questions with Taika Waititi. The New Zealand Herald, 8 March 2012. Available at: http://www.nzherald.co.nz/nz/news/article.cfm?c id=1\&objectid=10790473 (accessed 20 January 2013).

Debruge, P., 2010. Boy. Variety, 23 January. Available at: http:/www.variety.com/ review/VE1117941952?refcatid=31 (accessed 15 January 2011).

Douglas, N., 1994. Electric shadows in the South Seas: The Pacific Islands in films - a survey. In D. Aoki (ed.), Moving Images of the Pacific Islands: A Guide to Film and Video. Occasional Paper \#38. Honolulu: Center for Pacific Islands Studies, University of Hawaii, pp. 3-19.

Earl. E., 2005. Brand New Zealanders: The commodification of Polynesian youth identity in television advertising. In The Annual Meeting of the Australian and New Zealand Communication Association, Christchurch, New Zealand July 4-7, 2005. Available at: http://www.anzca.net/conferences/past-conferences/52-adam. html (accessed 23 December 2010).

-2006. The Commodification of Polynesian Youth Identity in bro'Town. Unpublished MA thesis, University of Canterbury, New Zealand.

Felperin, L., 2011. The Orator (Review). Variety, 19 September. Available at: http://variety. com/2011/film/reviews/the-orator-1117946168/ (accessed 15 February 2013).

Foster, R.J., 2008. Coca-Globalization: Following Soft Drinks from New York to New Guinea. New York: Palgrave Macmillan. 
Geiger, J., 2002. Imagined islands: White shadows in the South Seas and cultural ambivalence. Cinema Journal 4 (3): 98-121.

2007. Facing the Pacific: Polynesia and the U.S. Imperial Imagination. Honolulu: University of Hawai'i Press.

Glynn, K. and A.F. Tyson, 2007. Indigeneity, media and cultural globalization: The case of Mataku, the Māori X-Files. International Journal of Cultural Studies 10 (2): 205-24.

Gray, J., 2006. Watching the Simpsons: Television, Parody, and Intertextuality. New York: Routledge University Press.

Hardy, A., 2012. Hidden gods - Religion, spirituality and recent New Zealand cinema. Studies in Australasian Cinema 6 (1): 11-27.

Hastings-McFall, N., S. Tekela-Smith and C. Charteris, 2000. 1 Noble Savage, 2 Dusky Maidens. Auckland: C. Charteris, N. Hastings-McFall, S. Tekela-Smith.

Havens, T., 2006. Global Television Marketplace. London: British Film Institute.

Henderson, A., 2004. Art and science: An interview with Chris Graham. Disrupt, Issue 4 (October).

2012. The Orator/Le Tulafale (Review). The Contemporary Pacific 24 (2): 434.

Hokowhitu, B., 2007. Understanding Whangara: Whale Rider as simulacrum. New Zealand Journal of Media Studies 10 (2): 22-30.

2012. Te Kapa o Taika: A Commentary on Boy. New Zealand Journal of Media Studies 13 (1): 109-19.

Huarcaya, S.M., 2012. A Commentary on Boy and the indigenous self. New Zealand Journal of Media Studies 10 (2): 102-5.

Jameson, F., 1991. Postmodernism, or, The Cultural Logic of Late Capitalism. Durham, N.C.: Duke University Press.

Kavka, M. and S. Turner, 2012. Boy and the Postcolonial Taniwha. New Zealand Journal of Media Studies 13 (1): 37-46.

Keown, M., 2008. Can't we all just get along?': bro'Town and New Zealand's creative multiculturalism. Moving Worlds: A Journal of Transcultural Writings 8 (2): 44-58.

Kihara, S. (2004-2005). Fa'afafine: In the Manner of a Woman. Sydney: Sherman Galleries, exhibition.

Kihleng, E. and T.K. Teaiwa, 2012. The Orator/Le Tulafale (Review). The Contemporary Pacific 24 (2): 434-38.

Lustyik, K., 2010. Transnational children's television: The case of Nickelodeon in the South Pacific. International Communication Gazette 72 (2): 171-90.

Lustyik, K. and P. Smith, 2009. From the Simpsons to 'The Simpsons of the South Pacific': New Zealand's first primetime animation, bro'Town. Television and New Media 11 (5): 331-49.

Mawyer, A., 1998. From photons to electrons: The film guide to moving images of the Pacific Islands. The Contemporary Pacific 10 (2) : 457-65.

McFarland-Tautau, M. and G.A. Hunkin, 2012. The Orator/Le Tulafale (Review). The Contemporary Pacific, 24 (2): 441-46.

McKenzie-Minifie, M., 2006. Product placement set to soar. The New Zealand Herald, 26 August. Available at: <http://www.nzherald.co.nz/business/news/article. cfm?c_id=3\&objectid=10397207> (accessed 25 January 2011). 
Misa, T., 2006. We can enjoy a laugh at ourselves but we're no bad joke. The New Zealand Herald, 27 September. Available at: http://www.nzherald.co.nz/nz/ news/article.cfm?c_id=1\&objectid=10403083\&ref=emailfriend (accessed 6 October 2010).

Mitchell, E., 2009. Elizabeth Mitchell talks bro'Town. Available at: http://screentalk. nzonscreen.com/interviews/elizabeth-mitchell-talks-bro'Town (accessed 2 December 2010).

Muiava, S. and T. Suaalii-Sauni, 2012. The Orator/Le Tulafale (Review). The Contemporary Pacific 24 (2): 438-41.

New Zealand Film Commission, 2010. New Zealand theatrical releases as at July 27 , 2010. Available at: http://www.nzfilm.co.nz/Search.aspx?searchText=Box\%20 Office\#Downloads (accessed 28 January 2011).

New Zealand Film Commission, 2013. Top fifteen New Zealand films released at New Zealand box office (to December 31 2012). Available at: http://www.nzfilm. co.nz/about-us/statistics (accessed 21 January 2013).

New Zealand on Air, 2011. Funding decisions. Available at: http://www.nzonair. govt.nz/funding/fundingsearchpages/fundingsearchmusic.aspx?, (accessed 3 January 2011).

Nippert, M., 2004. The Simpsons of the South Pacific. The New Zealand Listener 195 (3359) Available at: http://www.listener.co.nz/issue/3359/features/2630/ the simpsons_of the south_pacific.html, accessed 16 December 2010.

Pearson, S.R., 2010. The influence of fiction and cinematic excess on the factual: Pacific documentary and act of war. Journal of Pacific History 45 (1): 105-16.

Perrot, A., 2007. Pasifika-Identity or Illusion? The New Zealand Herald, 4 August. Available at: http://www.nzherald.co.nz/lifestyle/news/article.cfm?c_ $\mathrm{id}=6$ \&objectid=10455473.

Pihama, L., 2012. A short commentary on Boy. New Zealand Journal of Media Studies 10 (2): 97-101.

Raymond, R., 1997. 21st Sentry Cyber Sister by Pacific Sisters. Available at: http:// collections.tepapa.govt.nz/theme.aspx?irn=1547 (accessed December 2010).

Ross, M., 2003. Distribution case: Whale Rider. Daily Variety 280 (31/32): 30.

Scott, M., 1990. Whitewash: The acceptable image in television advertising. In P. Spoonley and W. Hirsh (eds), Between The Lines: Racism and the New Zealand Media. Auckland: Heinemann Reed, pp. 84-89.

Silverman, J., 2012. How hard was it for the highest grossing film of all time to get U.S. distribution? Very. Available at: http://www.tribecafilm.com/tribecaonline/ future-of-film/Boy-The-American-Release.html\#.UPyuFErQLfc (accessed 20 January 2013).

Smith, J.T., 2012. Shaking the frame: Taika Waititi's anti-anthropological edge. New Zealand Journal of Media Studies 13 (1): 66-76.

Smith, J.T. and O.R. Mercier, 2012. Introduction. In Special Issue on Taika Waititi's Boy. New Zealand Journal of Media Studies 13 (1): 1-13.

Somerville, A.T., 2005. In the (brown) neighbourhood: An Aotearoa-based Oceania. SPAN: Journal of the South Pacific Association for Commonwealth Literature and Language Studies 54/55: 68-75. 
Spratt, A., 2006. bro'Town faces racial flak. The New Zealand Herald, August 27 2006. Available at: http://www.nzherald.co.nz/multiculturalism/news/article. cfm?c_id=58\&objectid=10398267 (accessed 6 January 2011).

Tamaira, M., 2007. Samoan Wedding, and: No. 2 (Review). The Contemporary Pacific 19 (2): 653-57.

Teaiwa, T. and S. Mallon, 2005. Ambivalent kinships? Pacific People in New Zealand. In J. Liu, T. McCreanor, T. McIntosh and T. Teaiwa (eds), New Zealand Identities: Departures and Destinations. Wellington: Victoria University Press, pp. 207-29.

Toonboom News, 2006. April Newsletter. Available at: http://www.toonboom.com/ company/newsletter.php (accessed 10 January 2011).

Toumarkine, D., 2003. Newmarket-New player: Veteran indie exec Bob Berney guides indie distrib debut. Film Journal International 106 (3): 18-20.

Trouillot, M.R., 1991. Anthropology and the Savage slot: The politics and poetics of otherness. In R.G. Fox (ed.), Recapturing Anthropology: Working in the Present. Santa Fe, NM: School of American Research Press, pp. 17-44.

2003. Global Transformations: Anthropology and the Modern World. New York: Palgrave, MacMillan.

Wakefield, P., 2004. TV News: Simpsons of the South Pacific coming your way. OnFilm (July): 6.

Wichtel, D., 2010. Our BOY in Hollywood. The New Zealand Listener 3 April. Available at: http://www.listener.co.nz/issue/3647/features/15200/our_BOY_ in_hollywood.html (accessed 29 January 2011).

Film and Television Series

BOY. Dir. Taika Waititi. Perf. James Rolleston, Te Aho Aho Eketone-Whitu, Taika Waititi. Whenua Films, 2012. Film.

'bro'Town. TV3. Firehorse Films. New Zealand. 2004-2009.

Kaitangata Twitch. MTS. Production Shed TV. 2010.

Little House on the Prairie. NBC. United States, 1974-1983.

Mataku. South Pacific Pictures. New Zealand. 2002-2005.

Matariki. Dir. Michael Bennett. Perf. Jason Wu, Susana Tang, Michael Whalley. Filmwork. 2010. Film.

Moana: A Romance of Golden Age. Dir. Robert J. Flaherty. Perf. Ta'avale, Fa'angase. Famous Players Lasky, 1926. Film.

No. 2. Dir. Toa Fraser. Perf. Ruby Dee, Mia Blake, Rene Naufahu. Numero Films Ltd, 2006. Film.

Sione's Wedding. Dir. Chris Graham. Perf. Oscar Kightley, Iaheto Ah Hi, Shimpal Lelisi. South Pacific Pictures, 2006. Film.

Sione's 2: Unfinished Business. Dir. Simon Bennett. Perf. Oscar Kightley, Robbie Magasiva, Shimpal Lelisi. South Pacific Pictures, 2012. Film.

South Park. Comedy Central. United States 1997-present.

Tabu. Dir. F.W. Murnau. Perf. Matahi, Anne Chevalier. Murnau-Flaherty Productions, 1931. Film.

Tales From the Crypt. HBO. United States. 1989-1996. 
The G.C. TV3. Eyeworks Touchdown. New Zealand. 2012.

The Hills. MTV. United States, 2006-2010.

The Jersey Shore. MTV. United States. 2009-2012.

The Orator. Dir. Tusi Tamasese. Perf. Fa'afiaula Sanote, Tausili Pushparaj, Salamasina Mataia. Blueskin Films. 2011. Film.

The Simpsons. FOX. United States. 1989-present.

The Strength of Water. Dir. Armaghn Ballantyne. Perf. Isaac Barber, Hato Paparoa, Melanie Mayall-Nahi. Filmwork. 2009.

The Vintner's Luck. Dir. Niki Caro. Perf. Jérémie Renier, Keisha Castle Hughes. Ascension Films. 2009. Film.

White Shadows in the South Seas. Dir. W.S. Van Dyke. Perf. Monte Blue, Raquel Torres. MGM, 1928. Film.

X Files. FOX. United States. 1999-2002.

\begin{abstract}
Despite the sophistication of international audiences and the politically subversive work produced by postcolonial creatives in the Pacific, romanticism continues to profoundly shape critical discourses about film and television set in the South Pacific. This article examines how the criticism generated (and sometimes not generated) in academic studies and among film critics reflects persistent discourses of primitivism. Even politically progressive narratives find themselves subject to the gravity of romanticism. The sheer persistence of these assumptions that continue to cast Pacific subjects as timeless, innocent and primitive remind us of the resilience of what Trouillot calls "the Savage slot" (1991, 2003).
\end{abstract}

Keywords: Savage slot, Pasifika, bro'Town, Sione's Wedding, BOY 